\title{
Energy, Economic, and Environmental Assessment of Coriander Seed Production Using Material Flow Cost Accounting and Life Cycle Assessment
}

Majid Dekamin ( $\sim$ Dekamin@uma.ac.ir)

University of Malayer https://orcid.org/0000-0003-0185-9995

Kamran Kheiralipour

Ilam University

Reza Keshavarz Afshar

Colorado State University

\section{Research Article}

Keywords: Economic productivity, Energy efficiency, Environmental impacts, Greenhouse gases.

Posted Date: December 1st, 2021

DOI: https://doi.org/10.21203/rs.3.rs-1036265/v1

License: (c) (i) This work is licensed under a Creative Commons Attribution 4.0 International License.

Read Full License 


\section{Abstract}

The agricultural sector in the world is facing social expectations to reduce energy consumption and environmental impacts; and at the same producing enough food and fiber for the growing world population. The purpose of the present research to determine the economic, energy consumption, and environmental indicators in coriander seed production using novel approach of material flow cost accounting (MFCA) along with classical life cycle assessment (LCA). The positive output and negative energy were 25485 and $6742 \mathrm{MJ} \mathrm{ha}^{-1}$, respectively. Energy efficiency, net energy gain, specific energy, and energy productivity indicators were calculated as $0.6,-11944 \mathrm{MJ} \mathrm{ha}^{-1}, 17.4 \mathrm{MJ} \mathrm{kg}^{-1}$, and $0.06 \mathrm{~kg} \mathrm{MJ}^{-1}$, respectively. The average production cost was calculated as $588 \$ \mathrm{ha}^{-1}\left(334 \$ \mathrm{ton}^{-1}\right)$ whereas gross income was $1267 \$ \mathrm{ha}^{-1}\left(720 \$\right.$ ton $\left.^{-1}\right)$. The value of negative products in coriander production was estimated as $239 \$ \mathrm{ha}^{-1}\left(136 \$\right.$ ton $\left.^{-1}\right)$. Seed shedding at harvest and water loss due to inefficient irrigation system were found to be the major negative products (economic and energy) in the system that can enhance the system productivity upon improvement. The values of benefit costs ratio and economic productivity were 1.74 and $3 \mathrm{~kg} \mathrm{~S}^{-1}$, respectively. The acidification potential $\left(58.2 \mathrm{~kg} \mathrm{SO}_{2}\right.$ eq ton $\left.{ }^{-1}\right)$, global warming potential $\left(510 \mathrm{~kg} \mathrm{CO}_{2}\right.$ eq ton $\left.{ }^{-1}\right)$, photochemical oxidation potential $\left(0.13 \mathrm{~kg} \mathrm{C}_{2} \mathrm{H}_{4}\right.$ eq ton $\left.{ }^{-1}\right)$, and eutrophication potential $\left(23 \mathrm{~kg} \mathrm{PO}_{4}{ }^{-3}\right.$ eq ton $\left.{ }^{-1}\right)$ indicators were evaluated. The hotspots in point of economic (labor and seed shedding), energy use (nitrogen fertilizer and machinery) and energy loss (seed shedding), and environment (diesel fuel consumption) were determined which can be used to optimize coriander production through decreasing the material and energy consumption in the field. The results showed that MFCA combined with LCA is a powerful tool in identifying hotspots in crop production systems and can be used in developing more sustainable systems as well as in developing sustainability models.

\section{Introduction}

Agriculture is one of the most important contributors to greenhouse gas emissions on the global scale (Stocker, 2014). Pollutants from the agricultural sector enter the atmosphere, soil, and water sources directly and indirectly during agricultural operations as well as during manufacturing and on farm use of inputs such as fuel, chemical fertilizers, etc. (Gan et al., 2014). Meanwhile, the agricultural sector accounts for $5 \%$ of world energy consumption )Muller, 2009). Maximum production of agricultural commodities with the least amount of pollutants (especially carbon dioxide) and energy consumption should be on the agenda of the agricultural sector (Mostashari-Rad et al., 2020). The increase in crop yield in the lasts several decades has been mainly due to the increase use of input energy in the form of synthetic fertilizers and pesticides (Naseri et al., 2021). Such an increase has led to development of inefficient farming systems with notable environmental impact. The increasing trend of pollution sources and the consequences of climate pollution due to high energy consumption highlight the necessity of attempt to increase the efficiency of input and energy consumption on farms scale which in turn is expected to reduce the environmental impacts of the system as well (Kizilaslan, 2009; Khieralipour, 2020; Pourmehdi and Kheiralipour, 2020). Reducing input energy and environmental impacts, while maintaining 
or increasing economic performance, can increase sustainability of crop production systems. Energy and economic efficiency are usually measured by predetermined economic goals. Hence, there is a need for an accurate framework for simultaneously measuring economic, energy, and environmental impacts. In this regard, it is necessary to evaluate the economic function of crop production, energy consumption pattern, and environmental effects of agricultural activities with new methods, and based on the results, activities that have a high environmental burden and energy consumption must be modified or replaced by activities that are more efficient to achieve economic productivity (Nisar et al., 2021). Various approaches such as carbon footprint (Benbi, 2018), material flow cost accounting (Dekamin and Barmaki, 2019; Kheiralipour and Sheikhi, 2020), agro-environmental analysis (Meyer et al., 2009; Saber et al., 2020), cumulative energy demand (Mostashari-Rad et al., 2020) and life cycle assessment (Dekamin and Barmaki, 2018; Saber et al., 2020) has been applied to assess environmental aspects of the agricultural sector. Numerous studies have been conducted on economic and energy analysis and the environmental effects of crops in the world. Examples include the evaluation of energy and carbon footprint of saffron (Khanali et al., 2016), canola (Mousavi-Avval et al., 2011; Kheiralipour et al., 2017; Dekamin et al., 2018), wheat and sunflower (Unakıtan and Aydın, 2018), corn and lentil (Meena et al., 2021), orange (Alishah et al., 2019) sugarcane (Hiloidhari et al., 2021), and millet-mustard cropping system (Chaudhary et al., 2021). However, no study has been conducted to simultaneously assess the environmental, economic, and energy impacts of crop production using the material flow and energy costing (MFCA) combined with life cycle assessment (LCA).

Agriculture is currently associated with innovations in inputs that lead to environmental damages. In order to reduce the agricultural burdens, there are effective strategies to improve the efficiency of the production system by identifying the hot spots and eliminating or reducing those. One of these strategies is applying MFCA in combination with LCA method. These methods together, systematically, purposefully, and to a large extent accurately can measure the economic and environmental indicators. According to ISO 14040 and 14050, the LCA and MFCA methods are used based on the collection and assessment of inputs and outputs to determine the environmental and economic indicators in the production of a process, product, or system (IS014051, 2011; Standardization, 2006). The results of the LCA as an accurate tool received less attention from the economic sector because it had no economic aspect. But with the use of material flow and energy costing tools, this shortcoming is eliminated and so more logical and practical evaluations are obtained. The MFCA is a management tool that measures material flow in the crop production process in terms of physical and monetary value for management purposes (Ho et al., 2021; Kokubu and Kitada, 2015). In the LCA method, it is determined per functional unit how much environmental impact is produced. Since the ultimate goal of farming is food, fiber, and fuel production and economic benefit, these environmental effects are often overlooked because they have no economic value. The MFCA helps determine the economic value of these energy and material wastes and provides the incentive to reduce those. In MFCA, emissions and material wastes are looked at as a non-product (negative product) alongside the main product (positive product) and attribute material flow and energy to those. By reducing negative products (or the cost and energy hidden in the production process), a 
positive product can be added or the cost and energy required for a certain amount of product can be reduced (Wan and $\mathrm{Ng}, 2015)$.

Coriander (Coriandrum sativum L.) is an important medicinal plant with extensive application in health and beauty products. The fruits and vegetative parts of the coriander plant are used as medicinal herbs. The aroma of this plant is used in cosmetics, food, perfumery, beverage, and pharmaceutical industries as well (Hu et al., 2020). Production of coriander has a significant contribution to the rural areas of Iran and other countries in the Middle East. The economic, energy, and environmental impacts of coriander production yet to be evaluated. The purpose of this study was to provide a framework for LCA-MFCA to simultaneously measure environmental impacts and energy consumption as well as the cost of coriander seed production comprehensively.

\section{Materials And Methods}

The study focused on coriander production in Nahavand, Hamedan province, Iran. Coriander in this region

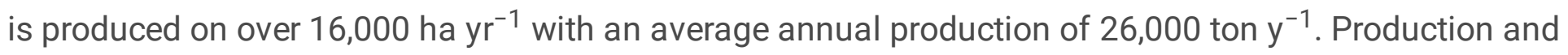
postharvest processing of coriander create significant job opportunities for locals in this region. Coriander is usually rotated with winter wheat (Triticum sativum). Efforts have been made to compare the results of coriander production with that of wheat in this paper.

In the first stage, the MFCA method was used to measure the quantity and economic values of the used or consumed materials and energy during the coriander seed production process. The most important feature of MFCA is tracking the materials and energy consumed and allocating these materials and energy to the products (positive or negative). This method is used as a reliable tool to calculate production costs and balance between inputs and outputs and can play the role of a management information tool and guidance to improve coriander seed production. In the MFCA method, the production of a crop is divided into several units for ease and accuracy of measurements. Each of these divisions is called a quantity center (QC). During each stage of land preparation, planting, growing, and harvesting coriander crop does not have a specific product. On the other hand, there is no clear demarcation for each of these stages, because the effect of some substances (such as fertilizers) that is used in one stage may be determined or observed in the next stage (such as leaching). Therefore, the whole process of coriander production from land preparation to coriander seed harvest was considered as one QC.

Life cycle assessment is recognized as an efficient tool for assessing the environmental impacts during the life cycle of products (Putra et al., 2020; Guinée, 2002; ISO, 2006). In the LCA method, all environmental effects are related to a specific functional unit (FU) (Adeleke et al., 2021). It can be said that the main feature of LCA is to help stakeholders make decisions in the value chain of crop production. Based on ISO 14040, ISO 14044, and ISO 14050, the LCA-MFCA methodology can be divided into four phases: goal and scope definition, material and energy inventory, environmental impact assessment, and interpretation. 
The first step in implementing the MFCA-LCA methodology is to define the purpose and scope of the study, system boundary, and the functional unit (FU). This study aimed to investigate the environmental impacts, energy consumption pattern, and cost of coriander seed production. Based on the results, we can make suggestions to reduce material and energy waste, reduce environmental impact, and ultimately increase farmer profits. Two FU were considered for the production of coriander seed 1) production of one metric ton of coriander seeds in terms of energy, cost, and environmental indicators, and 2) unit of land (one ha). The results of these two FUs help to understand how the environmental impacts, energy pattern, and production cost change at the level of the agricultural phase allowing the farmer to make better decisions based on the results obtained. Fig. 1 shows the system boundary in this study. Since both, MFCA and LCA estimation require consideration of inputs and outputs in the system, the same system boundaries should be defined. The process of preparing the soil for cultivation, the processes related to planting and growing, and finally the harvesting were included in the system boundary.

The most common agricultural operations for coriander seed production in the region were considered. Also, the required inputs and average yield for coriander seed in the 2019-2020 crop season were obtained from official Agricultural Statistics and used in the analysis.

Coriander cultivation consists of seven sub-phases: soil preparation, fertilization, planting, irrigation, application of pesticides and herbicides, weeding, and harvesting. Data related to each of the sub-phases (rate of fertilizers, pesticides, herbicides, amount of irrigation water, seed rate, etc.) were acquired from the official statistics report which have been reviewed by agronomy experts before being used. The average price of agricultural inputs in 2019-2020 was used to estimate the flow of materials. Direct emissions due to input use were calculated based on different methods, coefficients, and using different sources (Table 1). 
Table 1

The on-farm emissions coefficients in coriander seed production (Holloway et al., 2006).

\begin{tabular}{|c|c|}
\hline Emission & Coefficient \\
\hline \multicolumn{2}{|l|}{ Fertilizers } \\
\hline$\frac{k g N O-N}{\mathrm{kgN}_{\text {in }} \text { chemicalfertilizerapplied }}$ & 0.012 (to air) \\
\hline$\frac{\mathrm{kgNO}_{3}^{-}-\mathrm{N}}{\mathrm{kgN}_{\text {in }} \text { chemicalfertilizerapplied }}$ & 0.3 (to water) \\
\hline$\frac{k g C O-C}{\text { kgUrea-N }}$ & 1.57 (to air) \\
\hline Diesel fuel burning & Data sheet from Ecoinvent database \\
\hline$\frac{g \mathrm{CO}-\mathrm{C}}{\text { kgdieselfuelburned }}$ & 1.01 (to air) \\
\hline \multicolumn{2}{|l|}{ Conversion of emissions } \\
\hline $\mathrm{kgCO}_{2}-\mathrm{Cto} \mathrm{kg}_{2}$ & $\frac{44}{12}$ \\
\hline$k g N_{2} \mathrm{O}-N$ to $\mathrm{kg} N_{2} \mathrm{O}$ & $\frac{44}{28}$ \\
\hline $\mathrm{kgNH}_{3}-\mathrm{Nto} \mathrm{kg} \mathrm{NH}_{3}$ & $\frac{14}{17}$ \\
\hline $\mathrm{kgNO}_{3}-\mathrm{Nto} \mathrm{kg} \mathrm{NO}_{3}$ & $\frac{14}{62}$ \\
\hline $\mathrm{kgP}_{2} \mathrm{O}_{5}$ to kg phosphorus & $\frac{62}{142}$ \\
\hline $\mathrm{kgN}$ to $\mathrm{kg} \mathrm{NO}_{2}$ & $\frac{46}{14}$ \\
\hline
\end{tabular}

Different energy coefficients were used to analyze the energy flow in the coriander seed production process (Table 2). 
Table 2

Energy equivalent of the inputs of coriander seed production.

\begin{tabular}{|c|c|c|c|}
\hline Input & Unit & $\begin{array}{l}\text { Energy equivalent (MJ } \\
\text { Unit }^{-1} \text { ) }\end{array}$ & References \\
\hline Diesel fuel & I & 47.8 & Kitani et al. (1999) \\
\hline Human labor & $\mathrm{h}$ & 1.96 & Rafiee et al. (2010) \\
\hline Machinery & $\mathrm{kg}$ & 62.7 & Kaltsas et al. (2007) \\
\hline Nitrogen $(\mathrm{N})$ & $\mathrm{kg}$ & 66.14 & Mohammadi and Omid (2010) \\
\hline $\begin{array}{l}\text { Phosphate } \\
\left(\mathrm{P}_{2} \mathrm{O}_{5}\right)\end{array}$ & $\mathrm{kg}$ & 12.44 & Mohammadi and Omid (2010) \\
\hline Potassium $\left(\mathrm{K}_{2} \mathrm{O}\right)$ & $\mathrm{kg}$ & 11.15 & Mohammadi and Omid (2010) \\
\hline Herbicide & $\mathrm{kg}$ & 238 & Rafiee et al. (2010) \\
\hline Insecticide & $\mathrm{kg}$ & 101.2 & Rafiee et al. (2010) \\
\hline Irrigation water & $\mathrm{m}^{3}$ & 1.02 & Acaroglu (1998) \\
\hline Seed & $\mathrm{kg}$ & 14.48 & Ozkan et al. (2004) \\
\hline \multicolumn{4}{|l|}{ Negative output } \\
\hline Irrigation water & $\mathrm{m}^{3}$ & 1.02 & Acaroglu (1998) \\
\hline $\begin{array}{l}\text { Nitrous oxide } \\
\left(\mathrm{N}_{2} \mathrm{O}\right)\end{array}$ & $\mathrm{kg}$ & 1.87 & $\begin{array}{l}\text { Calculated based on standard entropy of } \\
\text { formation }\end{array}$ \\
\hline Ammonia $\left(\mathrm{NH}_{3}\right)$ & $\mathrm{kg}$ & 2.7 & $\begin{array}{l}\text { Calculated based on standard entropy of } \\
\text { formation }\end{array}$ \\
\hline Nitrate $\left(\mathrm{NO}_{3}\right)$ & $\mathrm{kg}$ & 12.44 & $\begin{array}{l}\text { Calculated based on standard entropy of } \\
\text { formation }\end{array}$ \\
\hline Phosphorus & $\mathrm{kg}$ & 3.32 & $\begin{array}{l}\text { Calculated based on standard entropy of } \\
\text { formation }\end{array}$ \\
\hline Insecticide & $\mathrm{kg}$ & 101.2 & Rafiee et al. (2010) \\
\hline Herbicide & $\mathrm{kg}$ & 238 & Rafiee et al. (2010) \\
\hline \multicolumn{4}{|l|}{ Positive output } \\
\hline Coriander yield & kg & 14.8 & Ozkan et al. (2004) \\
\hline
\end{tabular}

It was necessary to determine the energy coefficients for negative products (such as irrigation water loss and seed shedding at harvest) and emissions. For this purpose, energy coefficients were used to determine the energy content of field emissions and wastes. In order to calculate the emission energy 
coefficients (negative products), the standard enthalpy of formation was used (Table 3-4). The energy content of inputs that did not undergo specific chemical changes was considered similar to inputs (such as irrigation water or seed loss during harvest).

Table 3

The positive and negative energy of coriander seed production.

\begin{tabular}{|c|c|c|}
\hline Indicator & Unit & Definition \\
\hline $\begin{array}{l}\text { Input } \\
\text { equivalent } \\
\text { energy }\end{array}$ & $\begin{array}{l}\text { MJ Unit } \\
\text { ha }^{-1}\end{array}$ & Energy input=Input*energy equivalent \\
\hline $\begin{array}{l}\text { Machinery } \\
\text { energy }\end{array}$ & MJ ha ${ }^{-1}$ & $\begin{array}{l}\text { Machinery energy }=\left(\text { Machine weight }(\mathrm{kg})^{\star} \text { energy equivalent }(\mathrm{MJ}\right. \\
\left.\left.\mathrm{kg}^{-1}\right)^{\star} \text { time machine used per unit area }\left(\mathrm{h} \mathrm{ha}^{-1}\right)\right) / \text { machine economic } \\
\text { lifetime }(\mathrm{h})\end{array}$ \\
\hline $\begin{array}{l}\text { Output } \\
\text { equivalent } \\
\text { energy }\end{array}$ & $\begin{array}{l}\text { MJ } \\
\text { Unit }^{-1} \mathrm{ha}^{-1}\end{array}$ & Energy output= output*energy equivalent \\
\hline $\begin{array}{l}\text { Emission } \\
\text { energy }\end{array}$ & $\mathrm{MJ} \mathrm{kg}^{-1}$ & $\begin{array}{l}\text { Emission energy }=\left(\text { Molar mass }\left(\mathrm{g} \mathrm{mol}^{-1}\right) / \text { standard enthalpy of }\right. \\
\left.\text { formation }\left(\mathrm{KJ} \mathrm{mol}^{-1}\right)\right)^{\star} 1000\end{array}$ \\
\hline
\end{tabular}

Table 4

Nitrogen emission energy coefficient calculation based on standard enthalpy of formation

\begin{tabular}{|llll|}
\hline Emission & $\begin{array}{l}\text { Molar mass } \\
(\mathbf{g ~ m o l e}\end{array}$ & $\begin{array}{l}\text { Energy equivalent } \\
(\mathbf{k J ~ m o l e}\end{array}$ & $\begin{array}{l}\text { Energy equivalent } \\
(\mathbf{M J ~ k g}\end{array}$ \\
\hline Nitrous oxide $\left(\mathrm{N}_{2} \mathrm{O}\right)$ & 44.00 & 82.50 & 1.88 \\
\hline Ammonia $\left(\mathrm{NH}_{3}\right)$ & 17.03 & 46.00 & 2.70 \\
\hline Nitrate $\left(\mathrm{NO}_{3}\right)$ & 62.00 & 206.00 & 3.32 \\
\hline
\end{tabular}

Fuel consumption by machinery was calculated based on the average work of machines in field work processes and their horse power. Emissions of air pollutants (including methane, carbon dioxide, nitrogen oxides, etc.) were determined using database emission factors (REFERENCE). Infrastructures (such as buildings, sheds, and roads) were not included in the evaluations because they had little effect on final product production due to their high lifetime. The Ecoinvent database 3.7 was used for background processes (Nemecek and Kägi, 2007).

The environmental indicators including global warming potential $\left(\mathrm{kg} \mathrm{CO}_{2}\right.$ eq), eutrophication $\left(\mathrm{kg} \mathrm{PO}_{4}{ }^{-3}\right.$ eq), acidification ( $\left.\mathrm{kg} \mathrm{SO}_{2} \mathrm{eq}\right)$, and photochemical oxidation $\left(\mathrm{kg} \mathrm{C}_{2} \mathrm{H}_{4}\right.$ eq) were calculated based on CMLIA baseline impact assessment model in SimaPro 9.1.1 Software. 
Energy indicators including energy productivity (EP), energy efficiency (energy ratio) (EUE), net energy gain (NEG), and specific energy (SE) were calculated to evaluate energy flow in coriander production shown in Table 5.

\section{Table 5}

Energy indices for coriander seed production.

\begin{tabular}{|lll}
\hline Indicator & Unit & Calculation formulas* \\
\hline Energy productivity (EP) & $\mathrm{kgMJ}^{-1}$ & $\mathrm{EP}=\frac{\mathrm{Y}\left(\mathrm{kgha}^{-1}\right)}{\mathrm{IE}\left(\mathrm{MJha}^{-1}\right)}$ \\
\hline Energy efficiency (EE) & - & $\mathrm{EUE}(\mathrm{ER})=\frac{\mathrm{OE}\left(\mathrm{MJha}^{-1}\right)}{\mathrm{IE}\left(\mathrm{MJha}^{-1}\right)}$ \\
\hline Net energy gain (NEG) & $\mathrm{MJha}^{-1}$ & $\mathrm{NEG}=\mathrm{OE}\left(\mathrm{MJha}^{-1}\right)-\mathrm{IE}\left(\mathrm{MJha}^{-1}\right)$ \\
\hline Specific energy (SE) & $\mathrm{MJkg}^{-1}$ & $\mathrm{SE}=\frac{\mathrm{IE}\left(\mathrm{MJha}^{-1}\right)}{\mathrm{Y}\left(\mathrm{kgha}^{-1}\right)}$
\end{tabular}

* $\mathrm{E}$ is energy input $\left(\mathrm{MJ} \mathrm{ha}{ }^{-1}\right), \mathrm{OE}$ stands for energy output $\left(\mathrm{MJ} \mathrm{ha}^{-1}\right)$, and $\mathrm{Y}$ is coriander seed yield $(\mathrm{kg}$ $\left.\mathrm{ha}^{-1}\right)$.

Economic indicators including gross value of production (GVP), gross income (GI), cost/benefit ratio (CBR), and economic productivity (EP) were calculated as shown in Table 6.

Table 6

Economic indices for coriander seed production.

\begin{tabular}{|c|c|c|}
\hline Indicator & Unit & Calculation formulas* \\
\hline Gross value of production (GVP) & $\$ \mathrm{ha}^{-1}$ & $G V P=Y\left(\mathrm{kgha}^{-1}\right) \times P\left(\$ \mathrm{~kg}^{-1}\right)$ \\
\hline Gross income (GI) & $\$$ ha $^{-1}$ & $\mathrm{GI}=\mathrm{GVP}\left(\$ \mathrm{ha}^{-1}\right)-\mathrm{VC}\left(\$ \mathrm{ha}^{-1}\right)$ \\
\hline Benefit cost ratio (BCR) & - & $\mathrm{BCR}=\mathrm{GVP}\left(\$ \mathrm{ha}^{-1}\right) / \mathrm{TC}\left(\$ \mathrm{ha}^{-1}\right)$ \\
\hline Economic productivity (EP) & $\mathrm{kg} \$^{-1}$ & $E P=Y\left(\mathrm{~kg} \mathrm{ha}^{-1}\right) / \mathrm{VC}(\$)$ \\
\hline
\end{tabular}

\section{Results And Discussion}




\subsection{Energy analysis}

Table 7 shows the input (consumption) and positive and negative output energies in coriander production. Input and output energies were calculated for one ha of land as well as for one ton of coriander seed. 
Table 7

Input-output energy flow of coriander seed production.

\begin{tabular}{|c|c|c|c|c|c|}
\hline Inputs & Unit & $\begin{array}{l}\text { Value (Unit } \\
\mathrm{ha}^{-1} \text { ) }\end{array}$ & $\begin{array}{l}\text { Energy } \\
\text { equivalent } \\
\text { (MJ unit }^{-1} \text { ) }\end{array}$ & $\begin{array}{l}\text { Energy value (MJ } \\
\mathrm{ha}^{-1} \text { ) }\end{array}$ & $\begin{array}{l}\text { Energy } \\
\text { value } \\
\left(\mathrm{MJ} \text { ton }^{-1}\right)\end{array}$ \\
\hline Diesel fuel & 1 & 108 & 47.80 & 5162 & 2933 \\
\hline Human labor & $\mathrm{h}$ & 303 & 1.95 & 591 & 336 \\
\hline Machinery & $\mathrm{kg}$ & 114 & 62.70 & 7147 & 4060 \\
\hline Nitrogen $(\mathrm{N})$ & $\mathrm{kg}$ & 150 & 66.14 & 9921 & 5637 \\
\hline $\begin{array}{l}\text { Phosphate } \\
\left(\mathrm{P}_{2} \mathrm{O}_{5}\right)\end{array}$ & $\mathrm{kg}$ & 75 & 12.44 & 933 & 530 \\
\hline $\begin{array}{l}\text { Potassium } \\
\left(\mathrm{K}_{2} \mathrm{O}\right)\end{array}$ & $\mathrm{kg}$ & 60 & 1.12 & 67 & 38 \\
\hline Herbicide & $\mathrm{kg}$ & 3 & 238.00 & 738 & 419 \\
\hline Fungicide & $\mathrm{kg}$ & 1 & 216.00 & 108 & 61 \\
\hline Insecticide & $\mathrm{kg}$ & 1 & 101.20 & 121 & 69 \\
\hline Irrigation water & $\mathrm{m}^{3}$ & 4930 & 1.02 & 5029 & 2857 \\
\hline Seed & $\mathrm{kg}$ & 60 & 14.48 & 869 & 494 \\
\hline SUM & & & & 30687 & 17436 \\
\hline \multicolumn{6}{|l|}{ Negative output } \\
\hline Seed shedding & $\mathrm{kg}$ & 229 & 14.48 & 3313 & 1882 \\
\hline Irrigation water & $\mathrm{m}^{3}$ & 2169 & 1.02 & 2213 & 1257 \\
\hline Ammonia (NH3) & $\mathrm{kg}$ & 37 & 2.70 & 101 & 57 \\
\hline Nitrate (NO3) & $\mathrm{kg}$ & 45 & 12.44 & 560 & 318 \\
\hline Phosphorus & $\mathrm{kg}$ & 4 & 3.32 & 12 & 7 \\
\hline Fungicide & $\mathrm{kg}$ & 2 & 216.00 & 362 & 205 \\
\hline Insecticide & $\mathrm{kg}$ & 0 & 101.20 & 27 & 16 \\
\hline Herbicide & $\mathrm{kg}$ & 1 & 238.00 & 154 & 88 \\
\hline SUM & & & & 6742 & 3831 \\
\hline
\end{tabular}




\begin{tabular}{|llllll|}
\hline Inputs & Unit & $\begin{array}{l}\text { Value (Unit } \\
\text { ha }^{-1} \text { ) }\end{array}$ & $\begin{array}{l}\text { Energy } \\
\text { equivalent } \\
\text { (MJ unit }\end{array}$ & $\begin{array}{l}\text { Energy value } \text { (MJ } \\
\text { ha }^{-1} \text { ) }\end{array}$ & $\begin{array}{l}\text { Energy } \\
\text { value }\end{array}$ \\
\hline Coriander yield & $\mathrm{kg}$ & 1760 & 14.48 & 25485 & (MJ ton $^{-1}$ ) \\
\hline
\end{tabular}

The average value of the total energy input was $30687 \mathrm{MJ} \mathrm{ha}^{-1}\left(17436 \mathrm{MJ}^{-1}\right.$ ). The positive output energy was $25485 \mathrm{MJ} \mathrm{ha}^{-1}$ and the negative energy was $6742 \mathrm{MJ} \mathrm{ha}^{-1}$. The average yield of coriander seed was $1760 \mathrm{~kg} \mathrm{ha}^{-1}$. For example, input energy for wheat production was reported as $43054 \mathrm{MJ} \mathrm{ha}^{-1}$ and output energy as $117407 \mathrm{MJ} \mathrm{ha}^{-1}$ (Ghasemi-Mobtaker et al., 2020). Based on the results, the total human labor required to produce coriander seed was calculated to be $303 \mathrm{~h} \mathrm{ha}^{-1}$ ( $591 \mathrm{MJ} \mathrm{ha}^{-1}$ ) mostly being used for hand weeding as well as two-stage harvesting. Among operations, weed control (especially at the beginning of emergence) is very important, and if weeds are not controlled effectively, the yield can be greatly reduced. Weed control is mainly done by hand weeding plus the use of herbicides. At harvest, plants are undercut first (usually by hand) then let too dry in the field before being picked and threshed using a combine (Fig. 1). This two-step operation is made to minimize seed shedding as direct combine can result in massive shedding and yield loss. Nitrogen fertilizer (5636 MJ ton ${ }^{-1}$ or $9921 \mathrm{MJ}$ $\mathrm{ha}^{-1}$ ) and machinery (4060 $\mathrm{MJ}$ ton $^{-1}$ or $7147 \mathrm{MJ} \mathrm{ha}^{-1}$ ) had a significant share in total energy input used in the production of coriander seed (Fig. 2). The high share of human labor compared to other crops shows that mechanization is lagging in coriander seed production. For instance, the human labor required to produce wheat in the same region was estimated to be $186 \mathrm{MJ} \mathrm{ha}^{-1}$ (Taghavifar and Mardani, 2015) which is $39 \%$ less labor compared to coriander seed production. Herbicide was accounted for 737 $\mathrm{MJ} \mathrm{ha}{ }^{-1}$ input energy for coriander seed production compared to $321 \mathrm{MJ} \mathrm{ha}^{-1}$ for wheat production (Taghavifar and Mardani, 2015). The reason for the higher consumption of herbicides in coriander is its lower competitiveness against weeds, especially at the beginning of the growing season which requires more frequent use of herbicides during its growth cycle. Insecticide consumption was $1.2 \mathrm{I} \mathrm{ha}{ }^{-1}$, which was equivalent to $121 \mathrm{MJ} \mathrm{ha}^{-1}$. The amount of insecticide used in the production of coriander seed was similar to that of wheat (Taghavifar and Mardani, 2015). The energy input of coriander seed was $868 \mathrm{MJ}$ $\mathrm{ha}^{-1}$ compared to $2387 \mathrm{MJ} \mathrm{ha}^{-1}$ in wheat (Taghavifar and Mardani, 2015). Coriander seed are smaller than wheat and are planted at lower rates which explains the difference between the energy equivalents of seed input in two crops.

The equivalent energy of the negative products was calculated using the standard enthalpy of formation and multiplied by the values of the wastes. Among the negative products, seed shedding during twostage harvesting had the largest share $\left(3313 \mathrm{MJ} \mathrm{ha}^{-1}\right)$ followed by irrigation water drainage (2212 $\mathrm{MJ}$ $\mathrm{ha}^{-1}$ ). One of the major energy/material waste (negative products) in coriander production process is seed shedding during two-stage harvesting. Seed shedding at harvest was found to be a hot spot in terms of energy conservation in coriander production followed by waste of irrigation water. Flood irrigation is 
the predominant irrigation method in this region which results in massive water loss. Adopting more efficient irrigation systems such as sprinkler or drip irrigation could improve energy efficiency in coriander production due to minimizing negative energy associated with water loss.

Table 8 shows the MFCA and CA based energy indicators of coriander farms. In conventional accounting, the negative products is not calculated. The results from both methods of accounting are presented in this paper. The EUE in the production of coriander seed was 0.61 in MFCA and 0.83 in conventional accounting. As explained previously, negative energy is not taken into account in conventional accounting method that's why efficiency is higher in this method. Compared to wheat, the EUE of coriander production was much lower than that of wheat (2.73) as reported by Ghasemi-Mobtaker et al. (2020) and Sahabi et al. (2016).

The NEG, SE, and EP indices for coriander seed production were $-11944 \mathrm{MJ} \mathrm{ha}^{-1}, 17.4 \mathrm{MJ} \mathrm{kg}^{-1}$, and 0.06 $\mathrm{kg} \mathrm{MJ}^{-1}$, respectively (Table 8). The EP for wheat crop has been reported in the range of 0.12 to 0.27 (Ghasemi-Mobtaker et al., 2020; Soltani et al., 2013), compared to 0.12 for rapeseed (Mousavi-Avval et al., 2011), and 0.19 for barley (Mobtaker et al., 2010b). The lower EP of coriander compared to these crops are due to a significantly lower yield of coriander per ha.

Table 8

MFCA and conventional energy ratios in coriander seed production.

\begin{tabular}{|llll|}
\hline Energy indices & Unit & MFCA & Conventional accounting \\
\hline Input energy & $\mathrm{MJ} \mathrm{ha}^{-1}$ & 30687 & 30687 \\
\hline Output energy & $\mathrm{MJ} \mathrm{ha}^{-1}$ & 18743 & 25485 \\
\hline Positive energy & $\mathrm{MJ} \mathrm{ha}^{-1}$ & 25485 & 25485 \\
\hline Negative energy & $\mathrm{MJ} \mathrm{ha}^{-1}$ & -6742 & 0 \\
\hline Energy efficiency & - & 0.61 & 0.83 \\
\hline Energy productivity & $\mathrm{kg} \mathrm{MJ}^{-1}$ & 0.06 & 0.06 \\
\hline Specific energy & $\mathrm{MJ} \mathrm{kg}^{-1}$ & 17.4 & 17.4 \\
\hline Net energy gain & $\mathrm{MJ} \mathrm{ha}^{-1}$ & -11944 & -5202 \\
\hline
\end{tabular}

\subsection{Economic assessment}


Table 9 shows the economic indicators of coriander seed production. The average gross income of coriander seed production was $440 \$ \mathrm{ha}^{-1}\left(258 \$\right.$ ton $\left.^{-1}\right)$. The value of coriander seed production was $1267.2 \$ \mathrm{ha}^{-1}\left(720 \$\right.$ ton $\left.^{-1}\right)$. The value of negative products in coriander seed production was estimated at $239 \$ \mathrm{ha}^{-1}\left(136 \$\right.$ ton $\left.^{-1}\right)$, which was $23 \%$ of the final value of coriander seed produced and $35 \%$ of variable costs for crop production. Accordingly, the gross income of $1028 \$ \mathrm{ha}^{-1}$ (1267 \$ ha-1 CA method) was calculated for coriander production (Fig. 3). Gross income was reported as $975 \$ \mathrm{ha}^{-1}$ using conventional accounting for wheat production (Sahabi et al., 2016). Human labor (303\$ ha-1) has the largest share (51\%) in total production cost. This presents both, challenges and opportunities. It is challenging because high labor reduces the net benefit from the production. Also it is an opportunity because coriander production creates significant job opportunities especially in this rural area. Machinery $\left(68 \$ \mathrm{ha}^{-1}\right)$, seed $\left(48 \$ \mathrm{ha}^{-1}\right)$, and irrigation water $\left(39 \$ \mathrm{ha}^{-1}\right)$ were found as other costly inputs in coriander production.

Among the negative products, the seed loss at harvest was the most effective factor in reducing farmers' incomes. The economic value of coriander seed shedding was estimated to be $183 \$ \mathrm{ha}^{-1}$. Irrigation water loss with an economic value of $18 \$ \mathrm{ha}^{-1}$ had the second largest share in negative products.

The BCR was calculated as 1.74 (2.15 in conventional accounting) for coriander seed (Table 10) compared to 2.33 for wheat (Ghasemi-Mobtaker et al., 2020), 2.09 for rapeseed (Unakitan et al., 2010), and 1.26 for alfalfa (Mobtaker et al., 2010a). The EP index for the production of coriander seed is $3 \mathrm{k}^{-1}$, this number shows that with one dollar you can produce $3 \mathrm{~kg}$ of coriander seed. 
Table 9

Cost flow of coriander seed production.

\begin{tabular}{|c|c|c|c|c|c|}
\hline Input & Unit & $\begin{array}{l}\text { Value } \\
\left(\text { Unit ha }^{-1}\right)\end{array}$ & $\begin{array}{l}\text { Price } \\
\left.\text { (\$ Unit }^{-1}\right)\end{array}$ & Total price $\left(\$ \mathrm{ha}^{-1}\right)$ & Total price $\left(\$\right.$ ton $\left.^{-1}\right)$ \\
\hline Diesel fuel & I & 108 & 0.024 & 2.6 & 1.5 \\
\hline Human labor & $\mathrm{h}$ & 303.0 & 1.00 & 303.0 & 172.2 \\
\hline Machinery & $\mathrm{kg}$ & 114.0 & 0.60 & 68.4 & 38.9 \\
\hline Nitrogen $(\mathrm{N})$ & $\mathrm{kg}$ & 255.0 & 0.14 & 34.7 & 19.7 \\
\hline Phosphate $\left(\mathrm{P}_{2} \mathrm{O}_{5}\right)$ & $\mathrm{kg}$ & 150.0 & 0.30 & 45.0 & 25.6 \\
\hline Potassium $\left(\mathrm{K}_{2} \mathrm{O}\right)$ & $\mathrm{kg}$ & 60.0 & 0.43 & 25.5 & 14.5 \\
\hline Herbicide & $\mathrm{kg}$ & 3.1 & 4.40 & 13.6 & 7.8 \\
\hline Fungicide & $\mathrm{kg}$ & 1.2 & 4.40 & 5.3 & 3.0 \\
\hline Insecticide & $\mathrm{kg}$ & 0.5 & 4.40 & 2.2 & 1.3 \\
\hline Irrigation water & $\mathrm{m}^{3}$ & 4930.0 & 0.01 & 39.4 & 22.4 \\
\hline Seed & $\mathrm{kg}$ & 60.0 & 0.80 & 48.0 & 27.3 \\
\hline Total production cost & & & & 587.8 & 334.0 \\
\hline \multicolumn{6}{|l|}{ Negative output } \\
\hline Irrigation water & $\mathrm{m}^{3}$ & 2169.20 & 0.01 & 17.3 & 9.9 \\
\hline Seed shedding & $\mathrm{kg}$ & 228.80 & 0.80 & 183 & 104 \\
\hline Ammonia $\left(\mathrm{NH}_{3}\right)$ & $\mathrm{kg}$ & 62.65 & 0.14 & 8.7 & 5.0 \\
\hline Nitrate $\left(\mathrm{NO}_{3}\right)$ & $\mathrm{kg}$ & 76.50 & 0.14 & 10.7 & 6.1 \\
\hline Phosphorus & $\mathrm{kg}$ & 7.50 & 0.3 & 2.2 & 1.3 \\
\hline Fungicide & $\mathrm{kg}$ & 1.67 & 4.40 & 7.4 & 4.2 \\
\hline Insecticide & $\mathrm{kg}$ & 0.65 & 4.40 & 8.8 & 5.0 \\
\hline Herbicide & $\mathrm{kg}$ & 0.27 & 4.40 & 1.1 & 0.7 \\
\hline Total cost & & & & 239.5 & 136.1 \\
\hline \multicolumn{6}{|l|}{ Positive output } \\
\hline Coriander yield & kg & 1760 & 0.72 & 1267.2 & 720.0 \\
\hline Total income & & & & 1267.2 & 720.0 \\
\hline
\end{tabular}


Table 10

Cost and return components of coriander seed production.

\begin{tabular}{|llll|}
\hline Cost and return components & Unit & MFCA & CA \\
\hline Gross production value & $\$$ ha $^{-1}$ & 1027 & 1267 \\
\hline Positive & $\$$ ha $^{-1}$ & 1267 & 1267 \\
\hline Negative & $\$$ ha $^{-1}$ & -239.5 & 0 \\
\hline Gross return & $\$$ ha $^{-1}$ & 440 & 679 \\
\hline Benefit-cost ratio & - & 1.74 & 2.15 \\
\hline Economic productivity & $\mathrm{kg} \mathrm{\$}^{-1}$ & 3 & 3 \\
\hline
\end{tabular}

\subsection{Environmental assessment}

Table 11 summarizes the results of characterization for environmental indicators in production of coriander seed with FU of one ha as well as one ton of product. The sources of impact for the GWP index are shown in Fig. 4. An average of $510 \mathrm{~kg} \mathrm{CO}_{2}$ eq was produced per ton of coriander seed $(897 \mathrm{~kg} \mathrm{CO} 2$ eq $\mathrm{ha}^{-1}$ ) which was mainly due to off-farm emissions, especially due to the diesel fuel. The emission of carbon dioxide from diesel fuel had the largest share in the GWP $\left(271 \mathrm{~kg} \mathrm{CO}_{2}\right.$ eq). This index for tobacco and canola production in Iran was calculated as $2624 \mathrm{kgCO}_{2}$ eq (Mirkarimi et al., 2021) and 1181 $\mathrm{kgCO}_{2}$ eq (Mousavi-Avval et al., 2017), respectively.

Characterization results for the EUP and $\mathrm{AC}$ indicators were $23 \mathrm{~kg} \mathrm{PO}_{4}{ }^{-3}$ eq ton ${ }^{-1}\left(40 \mathrm{~kg} \mathrm{PO}_{4}^{-3} \mathrm{eq} \mathrm{ha}^{-1}\right)$ and $58 \mathrm{~kg} \mathrm{SO}_{2}$ eq ton ${ }^{-1}\left(102 \mathrm{~kg} \mathrm{SO}_{2}\right.$ eq ha-1), respectively. In these two impact categories, on-farm emission had the largest share. The results obtained for these impacts categories were comparable with other crops such as soybean (Dekamin and Barmaki, 2018).

Photochemical oxidants are the result of a reaction between nitrous oxide and volatile organic compounds. Fig. 4 shows the PCOP indicator for the production of one ton of coriander seed. Diesel with $0.3 \mathrm{~kg} \mathrm{C}_{2} \mathrm{H}_{4}$ eq and nitrogen fertilizer with $0.2 \mathrm{~kg} \mathrm{C}_{2} \mathrm{H}_{4}$ eq had the highest share in this category.

The results showed that the production of coriander seed in the studied region is not in an optimal situation from the environmental perspective (especially due to emissions caused by the use of diesel and chemical fertilizers). The chemical fertilizers in the area are usually applied before rainfall. Rainfall times are not necessarily the same as when the plant needs most nutrients. Accordingly, there is no synchrony between crop's need and fertilizer application. Moreover, application of fertilizer before rain 
can increase chance of nutrient loss via leaching. Optimal and timely use of chemical fertilizers can reduce the environmental burden of coriander seed production in the region.

Table 11

The environmental indicators of coriander seed production.

\begin{tabular}{|c|c|c|c|}
\hline Impact category & Unit & Value (Unit ha ${ }^{-1}$ ) & Value (Unit ton ${ }^{-1}$ ) \\
\hline Global warming potential (GWP100a) & $\mathrm{kg} \mathrm{CO} 2$ eq & 897.38 & 509.88 \\
\hline Photochemical oxidation potential & $\mathrm{kg} \mathrm{C}_{2} \mathrm{H}_{4}$ eq & 0.13 & 0.08 \\
\hline Acidification potential & $\mathrm{kg} \mathrm{SO} \mathrm{eq}$ & 102.53 & 58.26 \\
\hline Eutrophication potential & $\mathrm{kg} \mathrm{PO}_{4}^{-3} \mathrm{eq}$ & 40.33 & 22.92 \\
\hline
\end{tabular}

\section{Conclusion}

Assessing the economic, energy, and environmental sustainability of the production chain is of particular importance. However, in addition to reducing the environmental impacts, agricultural production can be optimized in terms of materials and energy use. As a result, in addition to reducing the environmental impacts, more income is generated for the farmers, which in turn contributes to rural development. The aim of this study was to evaluate the sustainability of coriander seed production (economic analysis, energy consumption, and environmental impacts) using LCA-MFCA strategy.

Economic and energy indicators of coriander seed production were studied using MFCA and environmental indicators were calculated using LCA. The results of LCA-MFCA showed that in the production of coriander seed, the use of chemical fertilizers and diesel fuel creates the most environmental burdens. Optimal and timely use of chemical fertilizers can reduce the environmental loads. Production, packaging, and transportation of chemical fertilizers (off-farm) and their use in the production of coriander seed (in-farm) has the greatest environmental impacts compared to other inputs used. Accordingly, it can be said that reducing the use of chemical fertilizers (especially nitrogen fertilizer) can improve the environmental profile of coriander seed production in the studied region. Inclusion of $\mathrm{N}$ fixing legume sin rotation with coriander as well as the application of organic fertilizers such as farmyard manure can help to achieve this goal. From the energy perspective, the largest share of inputs in the production of coriander seed were related to nitrogen fertilizer and diesel fuel. The greatest energy loss in the production of coriander seed was related to the seed shedding during the harvest followed by irrigation water loss. It is possible to reduce energy and material waste in the production of coriander by using cultivars resistant to shedding and also using more efficient irrigation methods. In terms of energy indicators such as energy efficiency, coriander seed production has recorded lower indicators than other crops, which can be improved as seed loss and water loss is minimized from the economic standpoint, 
the highest cost of production was related to labor. Since farm labor are usually provided by the farmer's family in this region it is not a direct cost but more like a lost opportunity as those labors could get paid if work elsewhere. This problem can be solved by using mechanized equipment for weed control and harvesting.

The results of the present study showed the necessity of applying management strategies to optimize coriander seed production system to minimize the material and energy consumption and waste in the production process. The economic, energy, and environmental hotspots identified in this paper can be used to achieve this goal. The government policies may assist the farmers to manage and optimize the input consumption based on the economic aspects and specially the energy and environmental indicators.

\section{Declarations}

Authors' contributions: Majid Dekamin Conceptualization, Methodology, Software. Kamran Kheiralipour Writing- Original draft preparation, Software. Reza Keshavarz Afshar Visualization, Validation.

Data availability: All data generated or analyzed during this study are included in this published article.

Consent to participate: Not applicable.

\section{Compliance with ethical standards}

Competing interests: The authors declare that they have no competing interests.

Consent for publication: All authors mutually agreed to publish the work in this journal.

Conflict of interest: The authors declare no competing interests.

Ethics approval: Not applicable.

\section{References}

1. Acaroglu, M., (1998). Energy from biomass, and applications. University of Selcuk, Graduate School of Natural and Appl Sciences, University of Selcuk.

2. Adeleke, O., Akinlabi, S. A., Jen, T. C., \& Dunmade, I. (2021). Environmental impact assessment of the current, emerging, and alternative waste management systems using life cycle assessment tools: a case study of Johannesburg, South Africa. Environmental Science and Pollution Research, 1-16.

3. Alishah, A., Motevali, A., Tabatabaeekoloor, R., \& Hashemi, S. J. (2019). Multiyear life energy and life cycle assessment of orange production in Iran. Environmental Science and Pollution Research, 26(31), 32432-32445.

4. Benbi, D., (2018). Carbon footprint and agricultural sustainability nexus in an intensively cultivated region of Indo-Gangetic Plains. Science of the total environment 644, 611-623. 
5. Chaudhary, V.P., Chandra, R., Chaudhary, R., Bhattacharyya, R., (2021). Global warming potential and energy dynamics of conservation tillage practices for different rabi crops in the Indo-Gangetic Plains. Journal of Environmental Management 296, 113182.

6. Dekamin, M., Barmaki, M., (2018). Selecting the best environmental friendly oilseed crop by using Life Cycle Assessment, water footprint and analytic hierarchy process methods. Journal of Cleaner Production 198, 1239-1250.

7. Dekamin, M., Barmaki, M., (2019). Implementation of material flow cost accounting (MFCA) in soybean production. Journal of Cleaner Production 210, 459-465.

8. Dekamin, M., Barmaki, M., Kanooni, A., \& Meshkini, S. R. M. (2018). Cradle to farm gate life cycle assessment of oilseed crops production in Iran. Engineering in Agriculture, Environment and Food, 11(4), 178-185.

9. Gan, Y., Liang, C., Chai, Q., Lemke, R.L., Campbell, C.A., Zentner, R.P., (2014). Improving farming practices reduces the carbon footprint of spring wheat production. Nature Communications 5, 1-13.

10. Ghasemi-Mobtaker, H., Kaab, A., Rafiee, S., (2020). Application of life cycle analysis to assess environmental sustainability of wheat cultivation in the west of Iran. Energy 193, 116768.

11. Guinée, J. B. (2002). Handbook on life cycle assessment operational guide to the ISO standards, NewYork: Kluwer Academic.

12. Hiloidhari, M., Haran, S., Banerjee, R., Rao, A.B., (2021). Life cycle energy-carbon-water footprints of sugar, ethanol and electricity from sugarcane. Bioresource Technology 330, 125012.

13. Ho, J.Y., Ng, D.K., Wan, Y.K., Andiappan, V., (2021). Synthesis of wastewater treatment plant based on minimal waste generation cost: A material flow cost accounting (MFCA) approach. Process Safety and Environmental Protection 148, 559-578.

14. Holloway, S., Karimjee ,A., Makoto, A., Pipatti, R., Rypdal, K., (2006). Guidelines for national greenhouse gas inventories. Energy 2.

15. IS014051, I., (2011). Environmental management-Material flow cost accounting-General framework. International Organization for Standardization, Geneva.

16. Kaltsas, A.M., Mamolos, A.P., Tsatsarelis, C.A., Nanos, G.D., Kalburtji, K.L., (2007). Energy budget in organic and conventional olive groves. Agriculture, Ecosystems \& Environment 122, 243-251.

17. Khanali, M., Movahedi, M., Yousefi, M., Jahangiri, S., Khoshnevisan, B., (2016). Investigating energy balance and carbon footprint in saffron cultivation-a case study in Iran. Journal of Cleaner Production 115, 162-171.Kheiralipour, (2020). Environmental Life Cycle Impact Assessment. $1^{\text {st }}$ Edition, Ilam University Publication, llam Iran. (In Persian).

18. Kheiralipour, K. (2020). Environmental Life Cycle Assessment. $1^{\text {st }}$ Ed. Ilam University publication, Ilam, Iran.

19. Kheiralipour, K., Jafari Samrin, H., Soleimani, M. (2017). Determining the environmental impacts of canola production by life cycle assessment, case study: Ardabil Province. Iranian Journal of Biosystems Engineering. 48(4), 517-526. 
20. Kheiralipour, K., Sheikhi, N. (2021). Material and energy flow in different bread baking types. Environment, Development and Sustainability. 23, 10512-10527.

21. Kitani, O., Jungbluth, T., Peart, R.M., Ramdani, A., (1999). CIGR handbook of agricultural engineering. Energy and biomass engineering 5, 330.

22. Kizilaslan, H., (2009). Input-output energy analysis of cherries production in Tokat Province of Turkey. Applied Energy 86, 1354-1358.

23. Kokubu, K., Kitada, H., (2015). Material flow cost accounting and existing management perspectives. Journal of Cleaner Production 108, 1279-1288.

24. Meena, B.P., Biswas, A., Singh, M., Das, H., Chaudhary, R., Singh, A., Shirale, A., Patra, A.K., (2021). Energy budgeting and carbon footprint in long-term integrated nutrient management modules in a cereal-legume (Zea mays-Cicer arietinum) cropping system. Journal of Cleaner Production, 127900.

25. Meyer, L., Tsatsaronis, G., Buchgeister, J., Schebek, L., (2009). Exergoenvironmental analysis for evaluation of the environmental impact of energy conversion systems. Energy 34, 75-89.

26. Mirkarimi, S.R., Ardakani, Z., Rostamian, R., (2021). Economic and environmental assessment of tobacco production in Northern Iran. Industrial Crops and Products 161, 113171.

27. Mobtaker, H.G., Akram, A., Keyhani, A., (2010). Economic modeling and sensitivity analysis of the costs of inputs for alfalfa production In Iran: A case study from Hamedan province. Ozean journal of applied sciences 3, 313-319.

28. Mobtaker, H.G., Keyhani, A., Mohammadi, A., Rafiee, S., Akram, A., (2010b). Sensitivity analysis of energy inputs for barley production in Hamedan Province of Iran. Agriculture, Ecosystems \& Environment 137, 367-372.

29. Mohammadi, A., Omid, M., (2010). Economical analysis and relation between energy inputs and yield of greenhouse cucumber production in Iran. Applied energy 87, 191-196.

30. Mostashari-Rad, F., Ghasemi-Mobtaker, H., Taki, M., Ghahderijani, M., Saber, Z., Chau, K.-W., NabaviPelesaraei, A., (2020). Data supporting midpoint-weighting life cycle assessment and energy forms of cumulative exergy demand for horticultural crops. Data in brief 33, 106490.

31. Mousavi-Avval, S.H., Rafiee, S., Jafari, A., Mohammadi, A., (2011). Improving energy use efficiency of canola production using data envelopment analysis (DEA) approach. Energy 36, 2765-2772.

32. Mousavi-Avval, S.H., Rafiee, S., Sharifi, M., Hosseinpour, S., Notarnicola, B., Tassielli, G., Renzulli, P.A., Khanali, M., (2017). Use of LCA indicators to assess Iranian rapeseed production systems with different residue management practices. Ecological Indicators 80, 31-39.

33. Muller, A., (2009). Sustainable agriculture and the production of biomass for energy use. Climatic Change 94, 319-331.

34. Naseri, H., Parashkoohi, M. G., Ranjbar, I., \& Zamani, D. M. (2021). Energy-economic and life cycle assessment of sugarcane production in different tillage systems. Energy, 217, 119252.

35. Nemecek, T., Kägi, T., (2007). Life cycle inventory of agricultural production systems. Swiss Centre for Life Cycle Inventories, Dübendorf. Ecoinvent report 15. 
36. Nisar, S., Benbi, D.K., Toor, A.S., (2021). Energy budgeting and carbon footprints of three tillage systems in maize-wheat sequence of north-western Indo-Gangetic Plains. Energy 229, 120661.

37. Ozkan, B., Akcaoz, H., Fert, C., (2004). Energy input-output analysis in Turkish agriculture. Renewable energy $29,39-51$.

38. Pourmehdi, K., Kheiralipour, K. (2020). Assessing the effects of wheat flour production on the environment. Advances in Environmental Technology. 2, 111-117.

39. Putra, M. A., Teh, K. C., Tan, J., \& Choong, T. S. Y. (2020). Sustainability assessment of Indonesian cement manufacturing via integrated life cycle assessment and analytical hierarchy process method. Environmental Science and Pollution Research, 27, 29352-29360.

40. Rafiee, S., Avval, S.H.M., Mohammadi, A., (2010). Modeling and sensitivity analysis of energy inputs for apple production in Iran. Energy 35, 3301-330.

41. Saber, Z., Esmaeili, M., Pirdashti, H., Motevali, A., Nabavi-Pelesaraei, A., (2020). ExergoenvironmentalLife cycle cost analysis for conventional, low external input and organic systems of rice paddy production. Journal of Cleaner Production 263, 121529.

42. Sahabi, H., Feizi, H., Karbasi, A., (2016). Is saffron more energy and economic efficient than wheat in crop rotation systems in northeast Iran? Sustainable Production and Consumption 5, 29-35.

43. Soltani, A., Rajabi, M., Zeinali, E., Soltani, E., (2013). Energy inputs and greenhouse gases emissions in wheat production in Gorgan, Iran. Energy 50, 54-61.

44. Standardization, I.O.f., (2006). Environmental management: life cycle assessment; requirements and guidelines. ISO Geneva.

45. Stocker, T., (2014). Climate change 2013 :the physical science basis: Working Group I contribution to the Fifth assessment report of the Intergovernmental Panel on Climate Change. Cambridge university press.

46. Taghavifar, H., Mardani, A., (2015). Energy consumption analysis of wheat production in West Azarbayjan utilizing life cycle assessment (LCA). Renewable Energy 74, 208-213.

47. Unakıtan, G., Aydın, B., (2018). A comparison of energy use efficiency and economic analysis of wheat and sunflower production in Turkey: A case study in Thrace Region. Energy 149, 279-285.

48. Unakitan, G., Hurma, H., Yilmaz, F., (2010). An analysis of energy use efficiency of canola production in Turkey. Energy 35, 3623-3627.

49. Wan, Y.K., Ng, D.K., (2015). Synthesis and optimisation of total water network via material flow cost accounting (MFCA)-based approach. Chemical Engineering Transactions 45, 1519-1524.

\section{Figures}



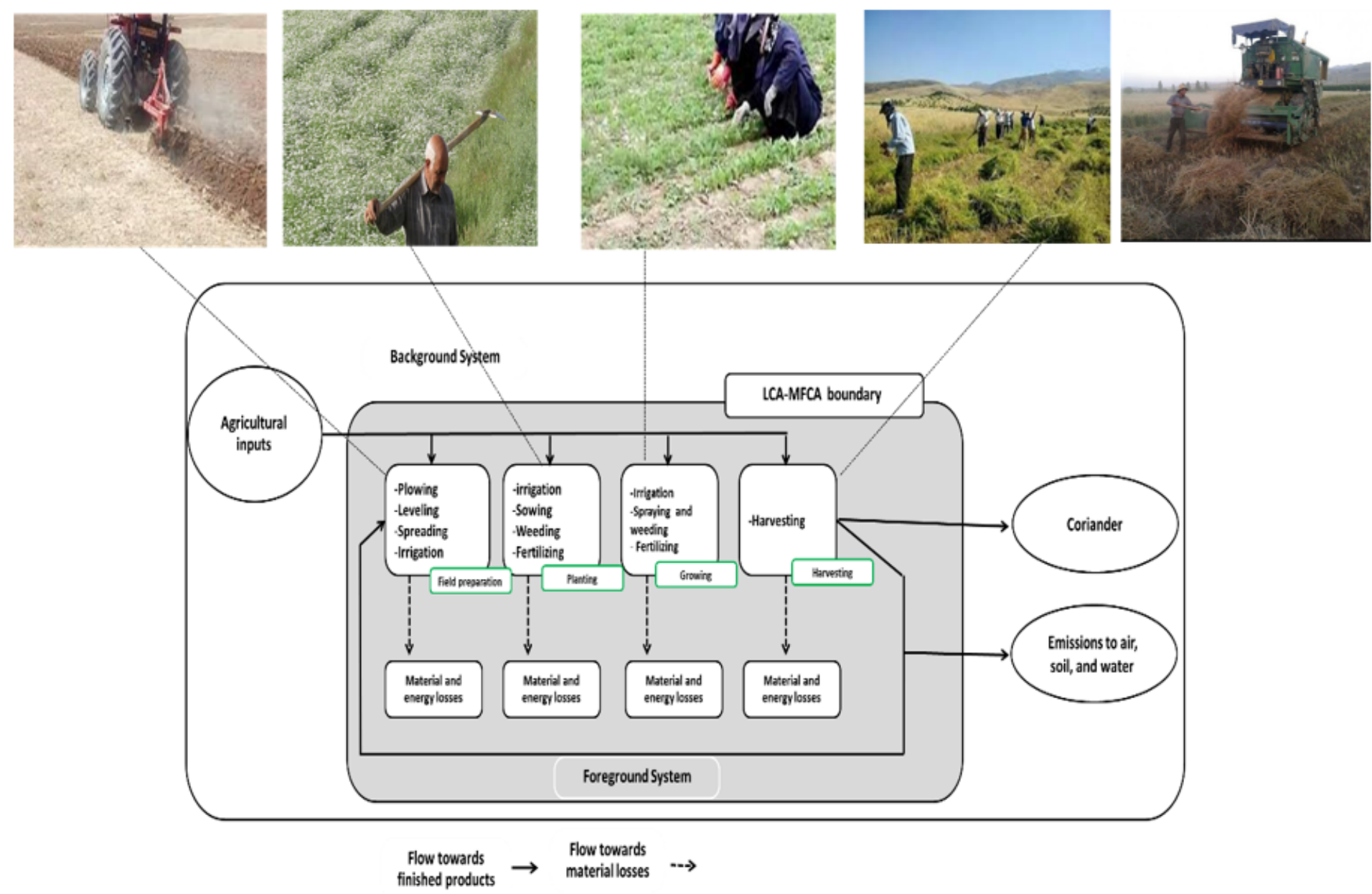

Figure 1

System boundaries in production of coriander seed. 


\section{Energy flow}

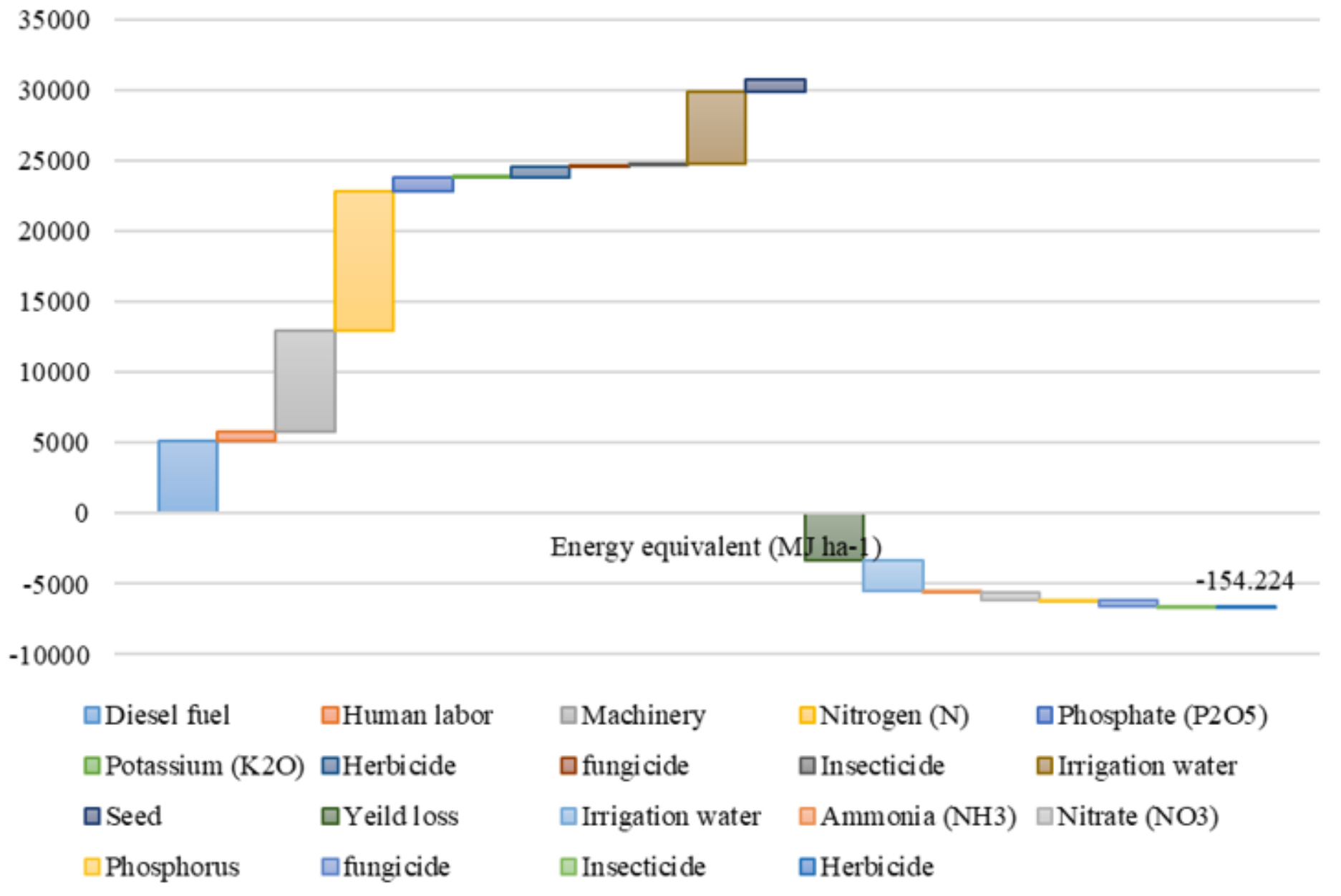

\section{Figure 2}

Energy flow (positive and negative energy) in the production of coriander seed. 


\section{Coriander costs}

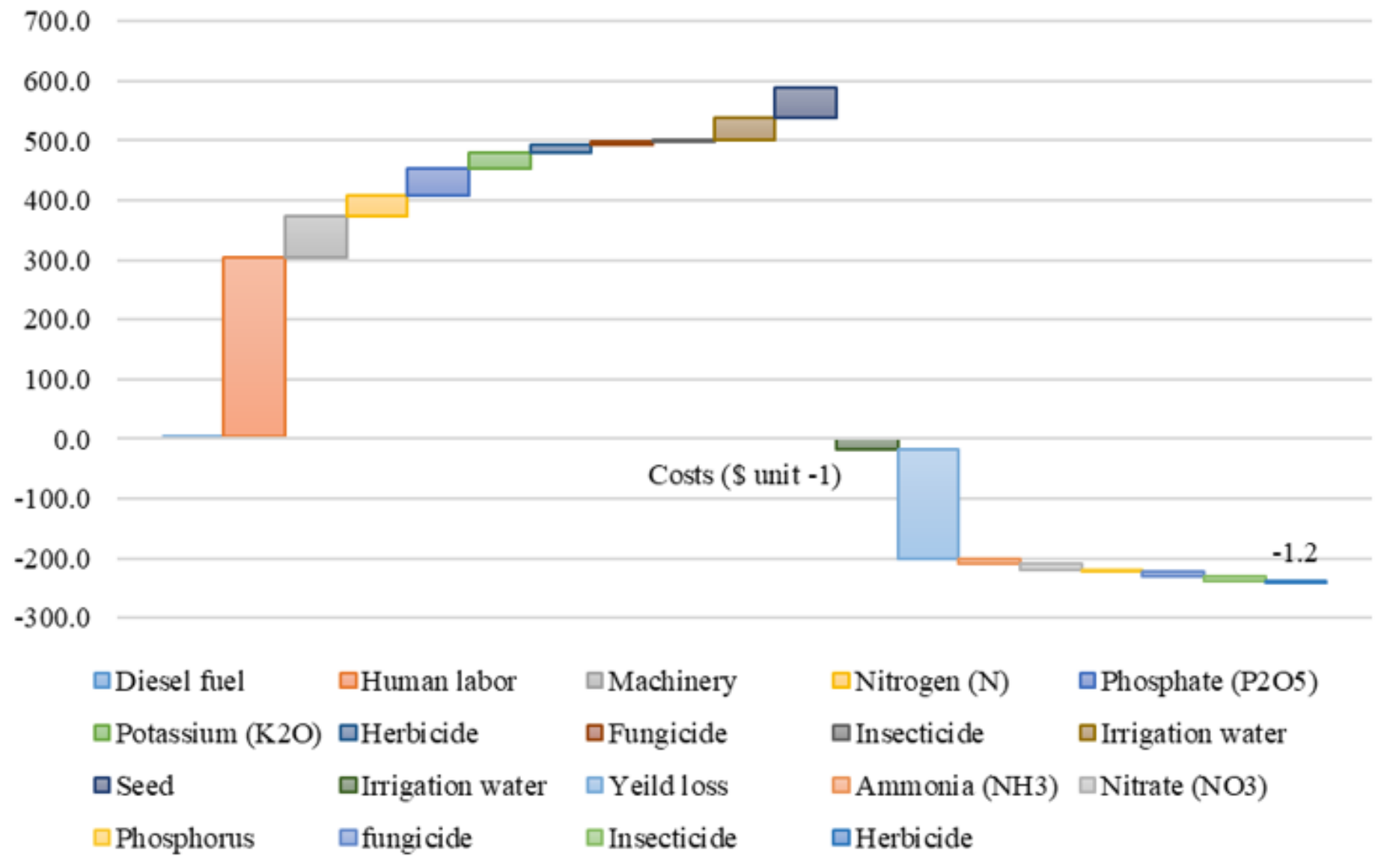

\section{Figure 3}

Coriander seed production costs (positive and negative). 

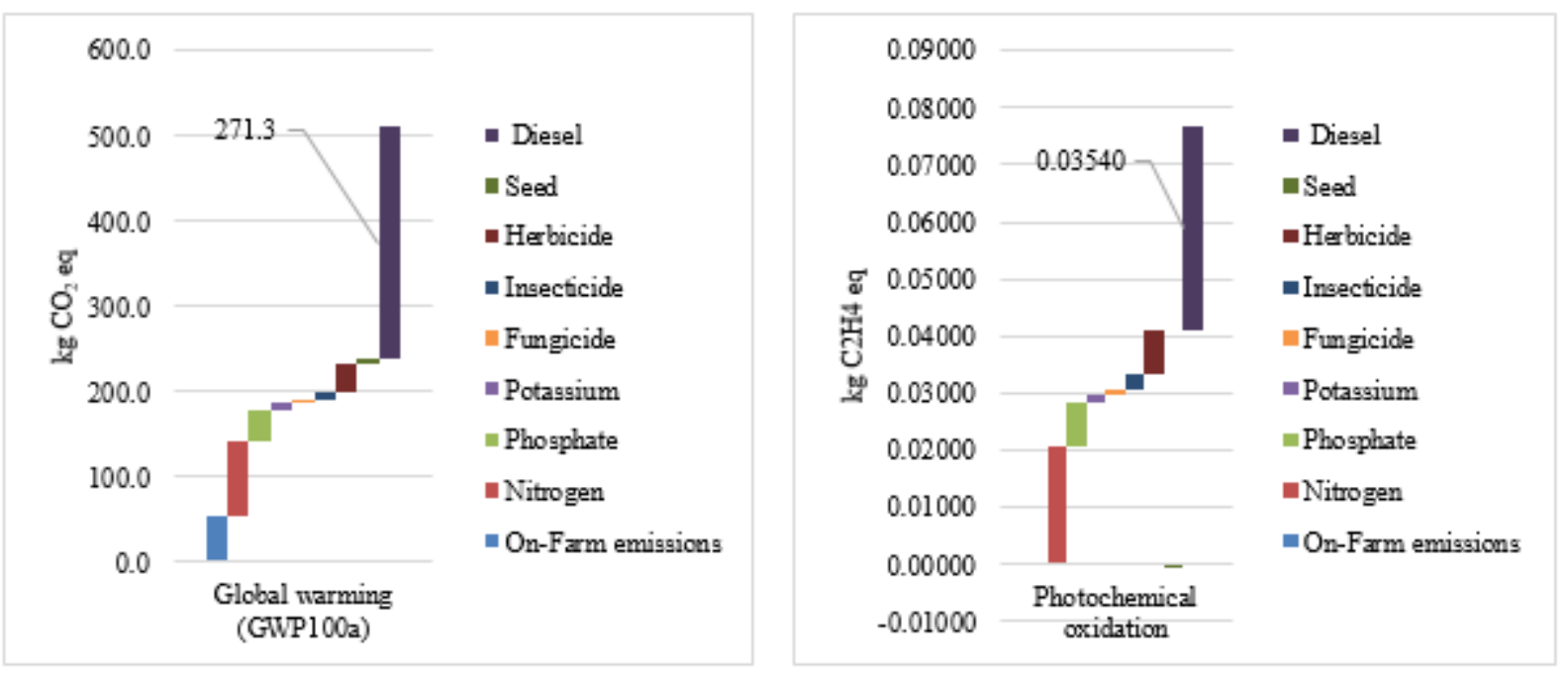

A

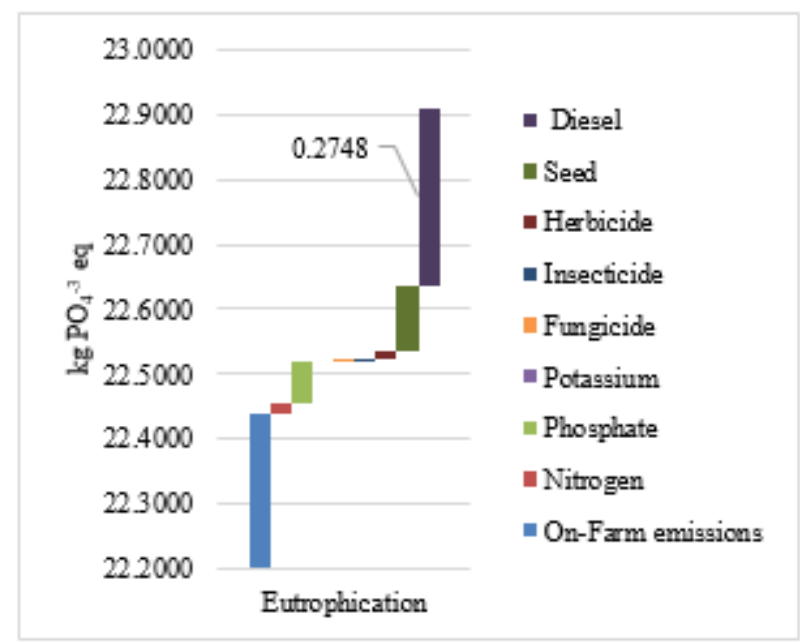

$\mathrm{C}$

\section{Figure 4}

The contribution of the factors to the environmental indicators, A) Global warming, B) Photochemical oxidation , C) Eutrophication, and D) Acidification.
B

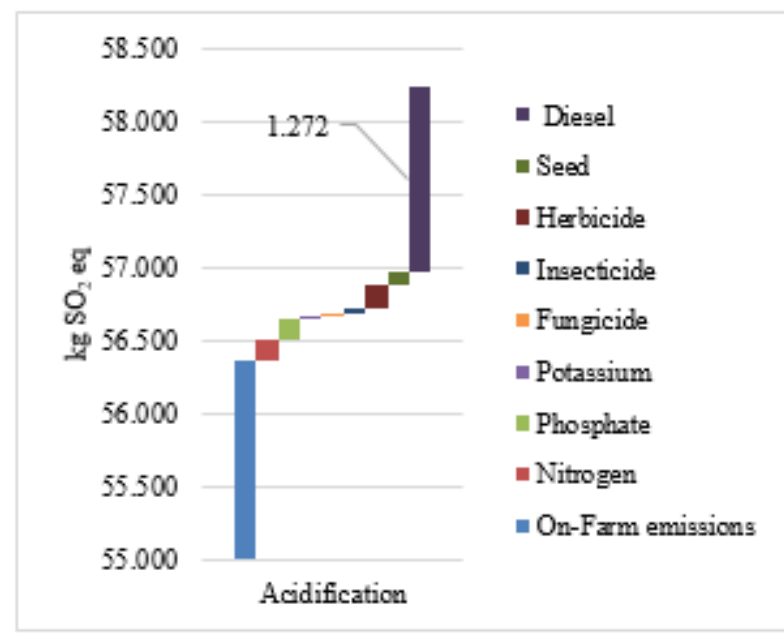

D 